\title{
Kepuasan Pasien Rawat Jalan terhadap Pelayanan Kefarmasian di Rumah Sakit dan Puskesmas di 11 Provinsi di Indonesia
}

\section{Outpatient Satisfaction with Pharmaceutical Sevices at Hospital and Primary Health Care in 11 Provinces in Indonesia}

\author{
Nita Prihartini*, Yuyun Yuniar, Andi Leny Susyanty, Raharni \\ Puslitbang Sumber Daya dan Pelayanan Kesehatan, Badan Litbangkes Kemkes RI, Jakarta, Indonesia \\ *Email : nita_200604@yahoo.com
}

Diterima: 15 April 2019

Direvisi: 6 September 2019

Disetujui: 17 Oktober 2019

\begin{abstract}
Abstrak
Pelayanan kefarmasian adalah suatu pelayanan langsung dan bertanggung jawab kepada pasien yang berkaitan sediaan farmasi dengan maksud untuk meningkatkan mutu kehidupan pasien. Penilaian terhadap mutu pelayanan kefarmasian dapat dilakukan berdasarkan kepuasan pasien rawat jalan. Tujuan penelitian yaitu membandingkan kepuasan pasien rawat jalan dalam pelayanan kefarmasian di rumah sakit (RS) dan puskesmas. Penelitian ini menggunakan desain studi komparatif potong lintang yang dilaksanakan pada bulan Februari-November 2017 di 11 provinsi mencakup 2 kabupaten/kota yang dipilih secara purposive. Sampel adalah pasien rawat jalan yang menebus obat di RS atau puskesmas dengan jumlah minimal 31 orang per pelayanan kefarmasian. Kepuasan diukur dengan dimensi ketanggapan, kehandalan, jaminan, keramahan, dan bukti fisik. Pengumpulan data dilakukan melalui angket. Analisis data menggunakan uji chi-square. Hasil penelitian menunjukkan kepuasan pasien rawat jalan terhadap pelayanan kefarmasian di RS 90,9\% dan di puskesmas 96,6\%. Persentase terbesar pasien rawat jalan di RS dan puskesmas adalah pada kelompok umur 40-59 tahun, jenis kelamin perempuan, pendidikan lanjutan, dan tidak bekerja/ibu rumah tangga. Ada perbedaan yang bermakna pada kelompok umur, jenis kelamin, dan pendidikan pasien rawat jalan antara RS dan puskesmas. Tidak ada hubungan yang bermakna antara karakteristik (umur, jenis kelamin, pendidikan, pekerjaan) pasien rawat jalan dengan kepuasan pelayanan kefarmasian di RS maupun puskesmas.

Kata kunci : Puskesmas; Rumah sakit; Kepuasan pasien; Pelayanan kefarmasian; Pasien rawat jalan
\end{abstract}

\begin{abstract}
Pharmaceutical services is a direct service and responsible to patients relating to pharmaceutical products aimed to improve the quality of life of patients. Quality of pharmaceutical services can be assessed based on outpatient satisfaction. The aim of the study was to compare the satisfaction of outpatients with pharmaceutical services in hospitals and primary health care. This study used a cross-sectional comparative study design and was conducted in February-November 2017 in 11 provinces, each province consisting of 2 districts/cities selected purposively. Samples were outpatients who got medicines in hospitals or primary health care at least 31 patients in each pharmacy. Satisfaction was assessed by the dimension of responsiveness, reliability, collateral, friendliness, and physical evidence. Data was collected by the questionnaires and analyzed using chi-square test. The results of the study show that outpatient satisfaction with pharmaceutical services in hospital and primary health care was 90,9\% and 96.6\%, respectively. The largest percentage of outpatients in hospitals and primary health care are in the age group of 40-59 years, female, has further education, and not working/housewives. There were significant differences in the age group, gender, and education of outpatients between hospitals and primary health care. There was no significant relationship between the characteristics (age, sex, education, occupation) of outpatients and satisfaction with pharmaceutical services in hospitals and primary health care.
\end{abstract}

Keywords: Primary health care; Hospital; Patient satisfaction; Pharmaceutical services; Outpatients 


\section{PENDAHULUAN}

Peraturan Pemerintah Nomor 51 Tahun 2009 tentang pekerjaan kefarmasian antara lain menyebutkan bahwa pekerjaan kefarmasian dalam pengadaan, produksi, distribusi atau penyaluran, dan pelayanan sediaan farmasi harus dilakukan oleh tenaga kesehatan yang mempunyai keahlian dan kewenangan untuk itu. Tenaga kesehatan yang kompeten dalam pekerjaan kefarmasian adalah apoteker dibantu oleh tenaga teknis kefarmasian (TTK). PP 51 Tahun 2009 menyatakan bahwa dalam menjalankan praktek kefarmasian pada fasilitas pelayanan kefarmasian, apoteker harus menerapkan standar pelayanan kefarmasian. Fasilitas pelayanan kefarmasian mencakup apotek, instalasi farmasi rumah sakit, puskesmas, klinik, toko obat, atau praktek bersama/klinik. ${ }^{1} \quad$ Permenkes Nomor 72 Tahun 2016 menyatakan rumah sakit adalah institusi pelayanan kesehatan yang menyelenggarakan pelayanan kesehatan perorangan secara paripurna yang menyediakan pelayanan rawat inap, rawat jalan, dan gawat darurat. ${ }^{2}$ Sedangkan dalam Permenkes Nomor 74 Tahun 2016 dinyatakan pusat kesehatan masyarakat yang selanjutnya disingkat puskesmas adalah unit pelaksana teknis dinas kesehatan kabupaten/kota yang bertanggung jawab menyelenggarakan pembangunan kesehatan di suatu wilayah kerja.

Permenkes Nomor 74 Tahun 2016 menyatakan pelayanan kefarmasian meliputi dua kegiatan, yaitu pengelolaan sediaan farmasi dan pelayanan farmasi klinik yang harus didukung oleh sumber daya manusia, sarana dan peralatan dalam rangka meningkatkan outcome terapi dan meminimalkan risiko terjadi efek samping obat untuk keselamatan pasien. Pelayanan kefarmasian yang dilakukan di RS dan puskesmas berupa pelayanan resep pasien rawat jalan yang umumnya peserta BPJS. Pihak RS maupun puskesmas harus memperhatikan kepuasan yang dirasakan oleh pasien dalam meningkatkan pelayanan. Kepuasan pasien dapat diukur dengan angket yang dibuat dalam upaya meningkatkan kunjungan pasien serta perlu dilakukan evaluasi kepuasan pasien terhadap pelayanan kefarmasian di RS dan puskesmas. $^{3}$

Kepuasan merupakan perasaan senang atau kecewa seseorang yang muncul setelah membandingkan persepsi antara harapan dan pelayanan yang diterimanya terhadap suatu jasa atau produk. Salah satu model yang banyak dipakai untuk mengukur kepuasan pelanggan adalah model SERVQUAL (Service Quality) dengan cara membuat survey penilaian kepuasan pelanggan. Analisis kepuasan pelanggan dapat dilakukan berdasarkan lima dimensi kualitas layanan, yakni sebagai berikut: tangible (bukti nyata) merupakan fasilitas/ sarana fisik yang dapat dilihat atau dirasakan pasien terkait pelayanan yang didapat dibandingkan dengan harapannya. Dalam penelitian ini adalah kemudahan akses lokasi apotek, kecukupan tempat duduk di ruang tunggu, kebersihan dan kenyamanan ruang tunggu, serta kelengkapan obat resep yang diterimanya; reliability (kehandalan) merupakan kemampuan tenaga kefarmasian memberikan pelayanan resep yang sesuai dengan harapan pasien. Dalam penelitian ini adalah kemudahan prosedur administrasi pasien BPJS menebus obat; responsiveness (ketanggapan) merupakan dimensi kualitas pelayanan yang paling dinamis, yaitu kecepatan tenaga kefarmasian memberikan pelayanan resep. Dalam penelitian ini adalah kecepatan petugas melayani pasien dan kecepatan peracikan obat resep; assurance (jaminan) merupakan dimensi kualitas yang berhubungan dengan kompetensi tenaga kefarmasian menanamkan kepercayaan dan keyakinan kepada pasien. Dalam penelitian ini adalah ketrampilan dan kemampuan tenaga kefarmasian memberikan informasi obat secara jelas dan lengkap kepada pasien; emphaty (empati) merupakan suatu kemampuan emosional tenaga kefarmasian untuk 
mengerti, menolong, dan merasakan apa yang dirasakan pasien. Dalam penelitian ini dimensi emphaty adalah keramahan tenaga kefarmasian memberikan pelayanan kepada pasien tanpa memandang status sosialnya. ${ }^{4}$

Kepuasan pasien dipengaruhi dua aspek yakni aspek pelanggan dan aspek pelayanan kefarmasian. Aspek pelanggan meliputi umur, jenis kelamin, pendidikan, pekerjaan, dan lokasi tinggal. Sedangkan aspek pelayanan kefarmasian terdiri dari dua faktor, yaitu aspek obat dan aspek non obat yang mencakup sikap dan pelayanan tenaga kefarmasian, kenyamaan dan kebersihan ruang tunggu, serta waktu tunggu obat. ${ }^{5}$ Penelitian yang dilakukan di RS PKU Muhammadiyah Wonogiri menunjukkan bahwa ada hubungan positif yang bermakna antara pelayananan kefarmasian dan kepuasan pasien. ${ }^{6}$

Tujuan penelitian ini adalah membandingkan kepuasan pasien dalam pelayanan kefarmasian antara RS dan puskesmas, serta menilai hubungan antara karakteristik pasien rawat jalan dan kepuasannya terhadap pelayanan kefarmasian di RS Kabupaten/Kota dan puskesmas. Informasi yang didapat diharapkan dapat memberikan masukan kepada pihak RS dan puskesmas untuk meningkatkan kualitas pelayanan kefarmasian kepada pasien rawat jalan.

\section{METODE}

Penelitian ini merupakan analisis lanjut dari penelitian Distribusi, Ketersediaan, Serta Pelayanan Obat dan Vaksin dalam Menghadapi Jaminan Kesehatan Semesta 2019. Penelitian tersebut menggunakan desain studi komparatif potong lintang yang dilaksanakan terhadap pasien rawat jalan di beberapa RS Kabupaten/Kota dan puskesmas pada bulan Februari-November 2017. Lokasi penelitian di lima regional di Indonesia sesuai Permenkes No. 27 Tahun 2014 tentang Petunjuk Teknis Sistem Indonesian Case Based Groups (INA-CBGs), berdasarkan sistem regionalisasi mencakup 11 provinsi, yaitu provinsi Jawa Barat, Jawa Timur, Sumatera Selatan. Nusa Tenggara Barat, DI Aceh, Sulawesi Utara, Sulawesi Selatan, Kalimantan Selatan, Kalimantan Tengah, Maluku Utara, dan Papua. Sampel penelitian adalah pasien rawat jalan dewasa yang menebus obat di RS dan puskesmas yang diambil secara accidental sampling. Jumlah sampel dihitung menggunakan rumus studi komparatif potong lintang berdasarkan buku Sample Size Determination in Health Studies sebagai berikut: ${ }^{7}$

$n 1=n 2=\frac{\left(z_{\alpha \sqrt{2 P_{*}(1-P)}}+z_{\beta} \sqrt{P_{1}\left(1-P_{1}\right)+P_{2} \cdot\left(1-P_{2}\right)}\right)^{2}}{\left(P_{1}-P_{2}\right)^{2}}$

Keterangan:

$\mathrm{n} 1=\mathrm{n} 2=$ jumlah sampel minimal

$\mathrm{Z} \alpha=$ derajat kemaknaan pada tingkat kesalahan $5 \%(1,96)$

$\mathrm{Z} \beta=$ Power penelitian sebesar $80 \%=0,842$

$\mathrm{P} 1=$ Proporsi pasien rawat jalan yang puas dengan pelayanan $\mathrm{RS}=50,8 \%^{8}$

$\mathrm{P} 2$ = Proporsi pasien rawat jalan yang puas dengan pelayanan puskesmas $=81 \%^{9}$

Berdasarkan hasil perhitungan, jumlah sampel minimal yang diperlukan pada penelitian ini adalah 31 pasien untuk masing-masing $\mathrm{RS}$ dan puskesmas di setiap provinsi. Dua kabupaten/kota dipilih oleh Dinas Kesehatan Kabupaten/kota di masing-masing provinsi. Kemudian dari kabupaten/kota diambil 1 RSU kabupaten/kota dan 2 puskesmas. Pengumpulan data menggunakan kuesioner angket yang disusun berpedoman pada skala Likert, dibuat 4 kategori, yaitu sangat memuaskan, memuaskan, kurang memuaskan, dan tidak memuaskan. Kategori ini dapat dikuantifikasi dengan skoring, yaitu skor 4 untuk sangat memuaskan, skor 3 untuk memuaskan, skor 2 untuk kurang memuaskan, dan skor 1 untuk tidak memuaskan. Variable kepuasan dikelompokkan menjadi puas yang meliputi (sangat memuaskan dan memuaskan) dan kurang puas yang meliputi (kurang memuaskan dan tidak 
memuaskan). Pengolahan data dilakukan dengan tahapan editing, coding, entry data, dan cleaning. Analisis data univariat berupa distribusi frekuensi dan analisis data bivariat menggunakan Uji Chi-square. Variabel dimensi ketanggapan (responsiveness) meliputi kecepatan petugas melayani resep pasien, kejelasan informasi obat yang diberikan petugas, dan waktu tunggu pelayanan obat sejak diserahkan sampai selesai. Dimensi kehandalan (reliability) meliputi kemudahan administrasi menebus obat. Dimensi jaminan (assurance) meliputi kelengkapan obat yang didapat berdasarkan resep, dan kemudahan mengenali petugas karena seragam/tanda pengenal. Dimensi keramahan (emphaty) meliputi keramahan petugas dalam pelayanan resep. Dimensi bukti fisik (tangible) meliputi lokasi mudah dikenal dan terjangkau, kecukupan tempat duduk di ruang tunggu, kenyamanan dan kebersihan ruang tunggu, ketersediaan tempat untuk pelayanan resep dan Ketersediaan fasilitas untuk pasien: air minum, brosur obat, atau timbangan badan, dll.

\section{HASIL DAN PEMBAHASAN}

Jumlah responden yang diperoleh sebanyak 395 responden rumah sakit dan 416 responden puskesmas. Hasil karakteristik masing-masing responden yang dapat dilihat pada Tabel 1 .

Karakteristik pasien rawat jalan di RS dan puskesmas sebagian besar berada pada kelompok umur 40-59 tahun, jenis kelamin perempuan, pendidikan lanjutan, tidak bekerja/ibu rumah tangga dan berada di lokasi regional tiga. Ada perbedaan yang bermakna pada kelompok umur, jenis kelamin dan pendidikan pasien rawat jalan antara RS dan puskesmas.

Pembagian kepuasan pasien rawat jalan sesuai dengan dimensinya dapat dilihat pada Tabel 2. Kepuasan pasien rawat jalan terhadap pelayanan kefarmasian di RS 90,9\% dan di puskesmas 96,6\%. Skor tertinggi kepuasan pasien dalam pelayanan kefarmasian adalah pada dimensi kehandalan (reliability) dan skor terendah pada dimensi bukti fisik (tangible), yaitu ketersediaan fasilitas untuk pasien (air minum, brosur obat, timbangan badan atau lainnya) dan kecukupan tempat duduk di ruang tunggu RS dan puskesmas. Kepuasan pasien rawat jalan di RS lebih rendah secara bermakna daripada di puskemas pada dimensi ketanggapan (responsiveness), kehandalan (reliability), jaminan (assurance) dan bukti fisik (tangible), tetapi tidak berbeda pada dimensi keramahan (emphaty).

Tabel 1. Karakteristik pasien BPJS rumah sakit dan puskesmas di 11 provinsi di Indonesia tahun 2017

\begin{tabular}{|c|c|c|c|c|c|}
\hline \multirow{2}{*}{ Karakteristik Pasien BPJS } & \multicolumn{2}{|c|}{ Rumah Sakit } & \multicolumn{2}{|c|}{ Puskesmas } & \multirow{2}{*}{$\begin{array}{c}\text { Nilai } \\
\mathbf{p}\end{array}$} \\
\hline & Jumlah & $\%$ & Jumlah & $\%$ & \\
\hline \multicolumn{6}{|l|}{ Umur } \\
\hline - kurang 40 tahun & 134 & 33,9 & 220 & 52,9 & \\
\hline - $40-59$ tahun & 171 & 43,3 & 150 & 36,1 & 0,000 \\
\hline - 60 tahun keatas (lansia) & 90 & 22,8 & 46 & 11,0 & \\
\hline \multicolumn{6}{|l|}{ Jenis kelamin } \\
\hline - Laki-laki & 148 & 37,5 & 120 & 28,8 & 0,009 \\
\hline - Perempuan & 247 & 62,5 & 296 & 71,2 & \\
\hline \multicolumn{6}{|l|}{ Pendidikan } \\
\hline - Pendidikan dasar (tidak/tamat SLTP) & 146 & 37,0 & 194 & 46,6 & 0,005 \\
\hline - Pendidikan lanjutan (tamat SLTA ke atas) & 249 & 63,0 & 222 & 53,4 & \\
\hline \multicolumn{6}{|l|}{ Pekerjaan } \\
\hline - Pelajar/mahasiswa & 18 & 4,6 & 16 & 3,8 & \\
\hline - Bekerja & 186 & 47,0 & 170 & 40,9 & 0,142 \\
\hline - Tidak/belum bekerja/ibu rumah tangga & 191 & 48,4 & 230 & 55,3 & \\
\hline
\end{tabular}


Tabel 2. Kepuasan pasien BPJS terhadap pelayanan kefarmasian di rumah sakit dan puskesmas di 11 provinsi di Indonesia tahun 2017

\begin{tabular}{|c|c|c|c|c|c|}
\hline \multirow[b]{2}{*}{ Pernyataan Tentang Kepuasan } & \multicolumn{2}{|c|}{ Rumah Sakit (\%) } & \multicolumn{2}{|c|}{ Puskesmas (\%) } & \multirow[b]{2}{*}{ Nilai $p$} \\
\hline & Puas & $\begin{array}{l}\text { Kurang } \\
\text { Puas }\end{array}$ & Puas & $\begin{array}{l}\text { Kurang } \\
\text { Puas }\end{array}$ & \\
\hline \multicolumn{6}{|l|}{ Dimensi ketanggapan (responsiveness) } \\
\hline Kecepatan petugas melayani resep pasien & 79,0 & 21,0 & 90,6 & 9,4 & 0,000 \\
\hline Kejelasan informasi obat yang diberikan petugas & 91,6 & 8,4 & 93,0 & 7,0 & 0,459 \\
\hline $\begin{array}{l}\text { Waktu tunggu pelayanan obat sejak diserahkan } \\
\text { sampai selesai tidak lama }\end{array}$ & 74,2 & 25,8 & 89,9 & 10,1 & 0,000 \\
\hline \multicolumn{6}{|l|}{ Dimensi kehandalan (reliability) } \\
\hline Kemudahan administrasi menebus obat & 94,4 & 5,6 & 97,4 & 2,6 & 0,035 \\
\hline \multicolumn{6}{|l|}{ Dimensi jaminan (assurance) } \\
\hline Kelengkapan obat yg didapat berdasarkan resep & 79,2 & 20,8 & 89,9 & 10,1 & 0,000 \\
\hline $\begin{array}{l}\text { Kemudahan mengenali petugas karena } \\
\text { seragam/tanda pengenal }\end{array}$ & 85,6 & 14,4 & 89,2 & 10,8 & 0,121 \\
\hline \multicolumn{6}{|l|}{ Dimensi keramahan (emphaty) } \\
\hline Keramahan petugas dalam pelayanan resep & 92,9 & 7,1 & 93,3 & 6,7 & 0,841 \\
\hline \multicolumn{6}{|l|}{ Dimensi bukti fisik (tangible) } \\
\hline Lokasi mudah dikenal dan terjangkau & 95,4 & 4,6 & 97,6 & 2,4 & 0,093 \\
\hline Kecukupan tempat duduk di ruang tunggu & 72,2 & 27,8 & 78,4 & 21,6 & 0,400 \\
\hline Kenyamanan dan kebersihan ruang tunggu & 87,8 & 12,2 & 92,5 & 7,5 & 0,024 \\
\hline Ketersediaan tempat untuk pelayanan resep & 91,6 & 8,4 & 92,5 & 7,5 & 0,634 \\
\hline $\begin{array}{l}\text { Ketersediaan fasilitas untuk pasien: air minum, } \\
\text { brosur obat, atau timbangan badan, dll. }\end{array}$ & 43,0 & 57,0 & 44,2 & 55,8 & 0,732 \\
\hline Rerata & 90,9 & 9,1 & 96,6 & 3,4 & 0,001 \\
\hline
\end{tabular}

Penelitian yang dilakukan di RS Sumber Waras Jakarta pada tahun 2003 menyatakan sebanyak $39,2 \%$ pasien menyatakan puas dan $60,8 \%$ tidak puas terhadap pelayanan RS. Aspek bukti fisik (tangible) mempunyai skor kepuasan terendah (82\%) dan aspek perhatian (responsiveness) mempunyai skor kepuasan tertinggi (88\%). Analisis diagram Kartesius menunjukkan yang menjadi prioritas untuk segera diperbaiki adalah kebersihan kamar mandi/WC, kebersihan ruang tunggu, kecepatan menemukan dokumen rekam medis dan keramahan perawat melayani pasien $\mathrm{RS}^{5}$ Penelitian yang dilakukan di Puskesmas Margadana Kota Tegal menunjukkan variabel yang berpengaruh secara bermakna terhadap kepuasan konsumen adalah bukti fisik (tangibles) dan jaminan (assurance). ${ }^{10}$

Hasil penelitian Baros dkk menunjukkan hasil yang berbeda, yaitu rerata kepuasan terendah pada pasien rawat jalan RS adalah dimensi ketanggapan (responsiveness) dan kepuasan tertinggi pada dimensi bukti fisik (tangible). Tingkat Kepuasan pasien rawat jalan sebesar 50,8\% puas dan 49,2\% yang tidak puas. ${ }^{8}$ Hasil penelitian Suharno Narso (DKI Jakarta, 2012) menyatakan dimensi emphaty (keramahan) dan dimensi reliability (kehandalan) mempunyai hubungan positif dan signifikan terhadap loyalitas pasien untuk dating kembali, sedangkan dimensi tangible (fasilitas fisik) tidak signifikan terhadap loyalitas pasien. ${ }^{11}$ Muhammad Syafi'I melaporkan bahwa ketanggapan (responsiveness) dengan unsur waktu tunggu mempunyai perbedaan yang bermakna antara RS dan puskesmas, hasil ini sejalan dengan penelitian di RS yang menunjukkan tingkat kepuasan pasien terendah adalah mengenai waktu tunggu obat di apotek RS. ${ }^{12}$

Menurut penelitian yang dilakukan oleh Chandrawati dkk, tingkat kepuasan pasien terhadap pelayanan obat secara bermakna lebih tinggi pada puskesmas terakreditasi ISO $(98,66 \%)$ dibandingkan 
puskesmas tidak terakreditasi ISO $(87,25 \%)^{13}$

Penelitian oleh Einurkhayatun dkk, menunjukkan tingkat kesesuaian antara harapan dan kenyataan dengan dimensi keseluruhan kualitas pelayanan adalah $79,70 \%$. Sedangkan tingkat kesesuaian masing-masing dimensi meliputi wujud/tampilan $81,94 \%$, kehandalan $79,36 \%$, Daya tanggap $77,0 \%$, Jaminan $79,44 \%$ dan empati $80,88 \% .^{9}$ Hasil penelitian Veicy F. Gaghana menyebutkan bahwa pelayanan kesehatan di Puskesmas Tuminting menunjukkan bahwa 50,9\% puas terhadap kehandalan, $54,7 \%$ puas terhadap daya tanggap, $77,4 \%$ puas terhadap jaminan, $55,7 \%$ puas terhadap perhatian, 66\% puas terhadap bukti fisik kepada pasien BPJS sesuai dengan urutan yang paling tinggi dalam memuaskan pasien yaitu jaminan (assurance), bukti fisik (tangible), perhatian (emphaty), ketanggapan (responsiveness), dan kehandalan (reliability). ${ }^{14}$
Hasil penelitian Budiman dkk, kepuasan pasien dari seluruh dimensi terhadap pelayanan jamkesmas di wilayah Puskesmas Tanjungsari Kabupaten Bogor adalah sebesar $81,0 \%$. $^{15}$

Hubungan antara karakteristik dan kepuasan pasien rawat jalan dapat dilihat pada Tabel 3. Hasil penelitian ini menunjukan bahwa tidak ada hubungan yang bermakna antara karakteristik (umur, jenis kelamin, pendidikan, pekerjaan) responden dengan kepuasan pasien BPJS di RS dan puskesmas.

Penelitian sebelumnya yang dilakukan oleh Yuniar dkk menunjukkan presentase terbesar pasien BPJS umumnya merasa puas terhadap pelayanan obat di puskesmas dan RS. Hubungan antara karakteristik pasien BPJS (umur, jenis kelamin, pendidikan, dan pekerjaan) dan kepuasan terhadap pelayanan obat baik di puskesmas dan rumah sakit tidak bermakna. ${ }^{16}$

Tabel 3. Hubungan antara Karakteristik dan Kepuasan Pasien BPJS terhadap Pelayanan Kefarmasian di Rumah Sakit dan Puskesmas di 11 Provinsi di Indonesia Tahun 2017

\begin{tabular}{|c|c|c|c|c|c|c|}
\hline \multirow{2}{*}{ Karakteristik Pasien } & \multicolumn{3}{|c|}{$\begin{array}{l}\text { Kepuasan terhadap Pelayanan } \\
\text { Kefarmasian di RS }\end{array}$} & \multicolumn{3}{|c|}{$\begin{array}{c}\text { Kepuasan terhadap Pelayanan Kefarmasian } \\
\text { di Puskesmas }\end{array}$} \\
\hline & Puas (\%) & $\begin{array}{c}\text { Kurang } \\
\text { Puas }(\%)\end{array}$ & Nilai p & Puas $(\%)$ & $\begin{array}{c}\text { Kurang Puas } \\
(\%)\end{array}$ & Nilai p \\
\hline \multicolumn{7}{|l|}{ Umur } \\
\hline Dewasa muda ( $<40$ tahun) & 91,0 & 9,0 & \multirow{3}{*}{0,884} & 95,5 & 4,5 & \multirow{3}{*}{0,367} \\
\hline Dewasa tua (40-59 tahun) & 90,1 & 9,9 & & 98,0 & 2,0 & \\
\hline Lansia ( $\geq 60$ th) & 92,2 & 7,8 & & 97,8 & 2,2 & \\
\hline \multicolumn{7}{|l|}{ Jenis kelamin } \\
\hline Laki-laki & 93,9 & 6,1 & \multirow[b]{2}{*}{0,105} & 98,3 & 1,7 & \multirow[b]{2}{*}{0,221} \\
\hline Perempuan & 89,1 & 10,9 & & 95,9 & 4,1 & \\
\hline \multicolumn{7}{|l|}{ Pendidikan } \\
\hline Sampai tamat SLTP & 93,2 & 6,8 & \multirow[b]{2}{*}{0,231} & 98,5 & 1,5 & \multirow[b]{2}{*}{0,054} \\
\hline Tamat SLTA sampai PT & 89,6 & 10,4 & & 95,0 & 5,0 & \\
\hline \multicolumn{7}{|l|}{ Pekerjaan } \\
\hline Bekerja & 91,6 & 8,4 & \multirow[b]{2}{*}{0,600} & 96,6 & 3,4 & \multirow[b]{2}{*}{0,996} \\
\hline $\begin{array}{l}\text { Tidak/belum bekerja/ibu } \\
\text { rumah tangga }\end{array}$ & 90,1 & 9,9 & & 96,6 & 3,4 & \\
\hline
\end{tabular}


Penelitian Koratiwida terhadap pasien rawat jalan di RS di Jakarta menunjukkan perempuan mempunyai hubungan bermakna dengan kepuasan terhadap pelayanan obat di RS. ${ }^{5 .}$ Pasien rawat jalan dengan pengetahuan baik memiliki kepuasan sebesar 1,528 kali dibandingkan pasien dengan pengetahuan cukup. ${ }^{8}$ Tidak ada hubungan bermakna antara karakteristik (umur, jenis kelamin, pendidikan, pekerjaan, jenis pembiayaan) dan kepuasan pasien di RS Semarang. ${ }^{17}$

Hasil penelitian di wilayah Puskesmas Tanjungsari Kabupaten Bogor menunjukkan tidak ada hubungan bermakna antara umur dan kepuasan pasien, tetapi ada hubungan bermakna antara jenis kelamin, pendidikan, pendapatan dan kepuasan pasien BPJS yang berobat di puskesmas. ${ }^{15}$ Wahyu Kuntoro melaporkan bahwa tidak ada perbedaan kepuasan pelayanan puskesmas berdasarkan karakteristik usia, jenis kelamin, dan pekerjaan, namun ada perbedaan kepuasan yang bermakna antara pendidikan rendah dan tinggi. ${ }^{18}$ Penelitian Christian Risnandi di Puskesmas Lingga Kabupaten Kubu Raya menyimpulkan bahwa ada hubungan bermakna antara pendidikan dan kepuasan pasien dan tidak ada hubungan bermakna antara usia, jenis kelamin, pekerjaan, dan kepuasan pasien rawat jalan. ${ }^{19}$

\section{KESIMPULAN}

Kepuasan pasien rawat jalan terhadap pelayanan kefarmasian di RS 90,9\% dan di puskesmas 96,6\%. Persentase terbesar pasien rawat jalan di RS dan puskesmas adalah pada kelompok umur 40-59 tahun, jenis kelamin perempuan, pendidikan lanjutan, dan tidak bekerja/ ibu rumah tangga. Ada perbedaan yang bermakna pada kelompok umur, jenis kelamin, dan pendidikan pasien rawat jalan antara RS dan puskesmas. Tidak ada hubungan yang bermakna antara karakteristik (umur, jenis kelamin, pendidikan, pekerjaan) pasien rawat jalan dengan kepuasan pelayanan kefarmasian di RS maupun puskesmas.

\section{SARAN}

Kepuasan pasien rawat jalan perlu ditingkatkan oleh pihak manajemen RS dan puskesmas dalam rangka meningkatkan mutu pelayanan. Hal-hal yang perlu diperhatikan, yaitu ketersediaan fasilitas untuk pasien (air minum, brosur obat, timbangan badan, atau lainnya), dan kecukupan tempat duduk di ruang tunggu pasien BPJS.

\section{UCAPAN TERIMA KASIH}

Ucapan terima kasih kami sampaikan kepada Prof. Sudibyo Supardi yang telah membantu mengumpulkan data penelitian, serta Puslitbang Sumber Daya dan Pelayanan Kesehatan, Badan Penelitian dan Pengembangan Kementerian Kesehatan Republik Indonesia selaku penyandang dana penelitian ini.

\section{DAFTAR PUSTAKA}

1. Republik Indonesia. Peraturan Pemerintah Nomor 51 Tahun 2009 tentang Pekerjaan Kefarmasian. Lembaran Negara Republik Indonesia Tahun 2009 Nomor 124. Jakarta: Sekretariat Negara; 2012.

2. Republik Indonesia. Peraturan Menteri Kesehatan Nomor 72 Tahun 2016 tentang Standar Pelayanan Kefarmasian di Rumah Sakit. Jakarta: Kementerian Kesehatan; 2016.

3. Republik Indonesia. Peraturan Menteri Kesehatan Nomor 74 Tahun 2016 tentang Standar Pelayanan Kefarmasian di Puskesmas. Jakarta: Kementerian Kesehatan; 2016.

4. Parasuraman A, Berry LL, Zeithaml VA. Guidelines for conducting service quality research. Marketing Research. 1990;2(6):34-44.

5. Koratiwida N. Hubungan karakteristik pasien dengan kepuasan terhadap pelayanan poliklinik umum Rumah Sakit Sumber Waras tahun 2003 [thesis]. Jakarta: Universitas Indonesia; 2003.

6. Rahmawati IN, Wahyuningsih SS. Faktor pelayanan kefarmasian dalam peningkatan kepuasan pasien di pelayanan kesehatan. Indonesian Journal on Medical Science. 2016;3(1):88-95. 
7. Lwanga, Kaggwa S, Lemeshow, Stanley, World Health Organization. Sample size determination in health studies: a practical manual / S. K. Lwanga and S. Lemeshow [Internet]. Geneva; World Health Organization; 1991 [cited 2019 April 10]. Available from: https://apps.who.int/iris/handle/10665/400 62

8. Baros WA. Kontribusi pengetahuan peserta Askes Sosial terhadap kepuasan layanan rawat jalan tingkat lanjut dan rawat inap PT Askes tahun 2011 [thesis]. Jakarta: Universitas Indonesia; 2012.

9. Einurkhayatun B, Suryoputro A, Fatmasari EY. Analisis tingkat kepuasan pasien terhadap kualitas pelayanan rawat jalan di Puskesmas Duren dan Puskesmas Bergas Kabupaten Semarang tahun 2017. Jurnal Kesehatan Masyarakat. 2017;5(4):33-42.

10. Nurcahyo H, Marchaban, Sumarni. Hubungan Kualitas Pelayanan rawat Jalan Pada Era Jaminan Kesehatan Nasional Terhadap Kepuasan Pasien. Jurnal Manajemen dan Pelayanan Farmasi. 2015;5(2):104-8.

11. Suharno N, Shihab MS. Pengaruh dimensi reliabilitas, dimensi tangibel dan dimensi empati terhadap loyalitas pasien. Jurnal Manajemen dan Bisnis Sriwijaya. 2012;10(19):1-16.

12. Syafii M. Tingkat kepuasan pasien dengan membandingkan antara persepsi dan harapan pasien di instalasi rawat jalan RSD dr. Soebandi Jember tahun 2011 [skripsi]. Jember: Univesitas Jember; 2011.

13. Candrawati AAAA, Suarjana IGK, Wirawan DN. Perbedaan kepuasan pasien pada puskesmas ISO dan puskesmas Non ISO di Kota Denpasar. Public Health and Preventive Medicine Archive. 2015 Jul;3(1):34-42. doi: 10.15562/phpma. v3i1.83

14. Gaghana VF, Siagian IET, Palandeng HMF. Tingkat kepuasan pasien Universal Coverage terhadap pelayanan kesehatan di Puskesmas Tuminting Manado. Jurnal Kedokteran Komunitas dan Tropik. 2014;2(1):22-6.

15. Budiman S, Herlina N. Hubungan status demografi dengan kepuasan masyarakat tentang pelayanan Jamkesmas di wilayah Puskesmas Tanjungsari Kabupaten Bogor Tahun 2010. Jurnal Kesehatan Kartika. 2010;1-17.

16. Yuniar Y, Handayani RS. Kepuasan pasien peserta Program Jaminan Kesehatan Nasional terhadap pelayanan kefarmasian di apotek. Jurnal Kefarmasian Indonesia. 2016;6(1):39-48.

17. Hidayati AN, Suryawati C, Sriatmi A. Analisis hubungan karakteristik pasien dengan kepuasan pelayanan rawat jalan Semarang Eye Center (SEC) Rumah Sakit Islam Sultan Agung Semarang. Jurnal Kesehatan Masyarakat. 2014;2(1):9-14.

18. Kuntoro W, Istiono W. Kepuasan pasien terhadap kualitas pelayanan di tempat pendaftaran pasien rawat jalan Puskesmas Kretek Bantul Yogyakarta. Jurnal kesehatan Vokasional. 2017;2(1):140-7.

19. Risnandi C. Faktor-faktor yang berhubungan dengan kepuasan pasien rawat jalan di Puskesmas Lingga Kabupaten Kubu Raya [skripsi]. Jakarta: Sekolah Tinggi Ilmu Kesehatan Saint Carolus; 2015. 